\title{
Internationalization of optical education
}

\section{Ludmila Gerasimova}

Ludmila Gerasimova, "Internationalization of optical education," Proc. SPIE 9663, Eighth International Topical Meeting on Education and Training in Optics and Photonics, 96631B (6 October 2003); doi: 10.1117/12.2207495

SPIE Event: Eighth International Topical Meeting on Education and Training in Optics and Photonics, 2003, Tucson, Arizona, United States 


\title{
Internationalization of Optical Education
}

\author{
Ludmila Gerasimova \\ IFMO University, St-Petersburg, Russia
}

The article is devoted to the problems of internationalization of education in optics. The importance and specific character of internationalization for optical education including its main problems are analyzed. The ways of international integration on the university level are presented through the model of "step by step" solution of education comparability. The importance of international university networks in optics is showed.

Each country has its own "optical school", with its traditions, history, strong scientific fields, famous teachers and researchers, etc. Internationalization of such national optical schools is one of important ways for improvement of the quality of university graduators in optics. Internationalization gives access to the best world experience, gives education closer connection with the world science and economics, directs toward international exchange of scientific knowledge and achievements. The following barriers can be mentioned on the way of internationalization: countries;

Difference between the university qualifying documents in different

Distinctions in the set of optical graduating specialties in universities in different countries;

Different contents of educational programs and courses;

Different status and role of department in a learning process;

Lack of educational programs and courses in English language in not English speaking countries;

Necessity of transition from a system of engineering training to a two-stage system " bachelor - master";

Foreign textbooks are not always accepted by national universities due to their orientation to another educational process; 
Absence of agreements between universities about mutual recognition of educational courses and programs;

Absence of evaluating systems for the courses taught in foreign universities;

Difference in basic (undergraduate) education;

Distinctions between educational systems is an objective obstacle for internationalization of education. Russian national standards limit capabilities of comparability of education received at foreign universities. However internationalization in the field of optical education has a number of considerable advantages and features making this process much easier here than in other technical and, especially, humanitarian fields.

At first, it is the high interest to optics and optical education in the countries keeping the high- standards in technical progress.

Secondly, it is uniqueness of optical education itself. Optics in itself is an elite science requiring severe fundamental physical and mathematical background and availability of unique laboratory facilities. As a result of such prerequisites the qualitative optical education can not appear in itself in any technical institute or university. It needs long time period of formation of its own "scientific schools" including scientific and pedagogical staff, traditions, building educational and scientific labs and departments with their strong fields of research and education. The elitism and uniqueness of optical education is generic for all countries. As an example we can see that even in technologically advanced countries there are only a few optical universities or optical faculties, whereas there are tens technical universities of a broad profile.

Therefore, in - third, the universities of an optical profile are put in expedient conditions in comparison with other technical universities. All of them are well-known both in international scientific environment and one to another, thereby determining a narrow circle of the potential partners. The specialization of different optical universities is also a positive argument for internationalization of optical education, creating the reasons for academic mobility. Optical students wishing to receive additional knowledge in optical specializations, which they can not get in their home university, get opportunity to travel abroad and as a result to become broader professionals.

International university networks is one of the main form of cooperation 
today between universities from different countries. It is practically impossible to find foreign university, not integrated in international university networks. Universities work in close co-operation, supplementing one another on different directions of preparation of the specialists. Therefore it is extremely important to create inter-networks of optical universities, integrating potentials of Unites States, Europe, Russia and Asia, for development of productive international cooperation in the field of optical education.

Fourth, an important point is the similarity of the contents of optical education programs at different universities in the world. The differences basically exist in techniques of teaching and in quantity of hours in the programs for the practical, laboratory and lecture components. There are also essential differences in a system of testing of student knowledge. The similarity of a context of education programs in optics all over the world leads to considerable simplification of comprehension of universities, to minimization of activities on comparability of courses and mutual recognition of education programs that is a good base for international cooperation in the academic field.

In fifth, optics and optical education as a consequence has priority at a state level for many advanced countries as a "Science of the 21 Century". This means that the level reached in the field of optics determines scientific and technological capabilities of the country.

The listed features demonstrate that internationalization in optical education has a number of advantages and thus demands smaller efforts for its implementation. An optical specialization of universities and the distinctions in the structure of educational process boost the academic mobility. The opportunities to get knowledge and skills from different foreign "optical schools", introduces exclusive interest for the students and teachers.

Internationalization of education is connected to its comparability and depends on the national doctrines of development of a higher education. National level is the case of the problems solution "from above". The approach "from below" - the university level is the most interesting to practice. Each optical high school is the subject of international relations. Universities have their contracts with the partners abroad, they receive international grants, train foreign students and postgraduate students, participate in international university networks. St.-Petersburg State Institute of Fine Mechanics and Optics (IFMO University) - the unique optical university in Russia, introduces its approach to solution of education comparability through development of short-courses modules in English language for the students 
from foreign universities. Short courses are the educational modules with the specific contents, which can be taught independently or supplement each other forming sub-programs and programs. The approach is based on the three-level model:

The first level - comparability of short modules/courses

The second level - comparability of the educational university courses

The third level - comparability of Education Programs (bachelor, master, specialist)

In brief this approach is based on the following steps made by the university on the way of internationalization of its education:

1) Negotiations with foreign universities about capability of certification of short educational modules (lectures, laboratory trainings, practical works), for example, according to European Credit Transfer System

2) Joint work of the teachers and international managers from IFMO and foreign universities on recognition of the short courses taught at IFMO in English as a constituent part of educational courses taught in foreign universities with giving the certain number of credits for each short course

3) Signing of the long-term interuniversity agreements about certification of short courses

4) Looking for financing for training students from foreign universities at IFMO University

5) Development of the long-distance short courses/modules for foreign students in English

6) Carrying out the training at IFMO University with its admission in foreign universities

7) Increase of amount of developed short courses/modules as parts of curriculum taught in foreign universities

8) Certification of the educational courses for foreign students at IFMO University on the basis of already certificated short-courses modules

9) Looking for financing for training of the students from foreign universities at IFMO University in the certificated educational courses 
10) Development and certification of Education Programs taught at IFMO (degree - bachelor, master, specialist)

11) Development of the academic mobility: students and teachers

12) Discussion of the obtained experience and results at the level of national Ministries of Education

13) Dissemination of results among other optical universities.

It is necessary to mark, that internationalization of the university education is connected with internationalization of all levels inside the university, namely:

First level - university administration (rector, administration).

Second level - functional management and control (pro-rectors on areas of activity - educational, scientific, etc.)

Third level is a level of faculties/institutes (deans of faculties)

Fourth level - last, but extremely relevant - level of university departments.

For common success, internationalization as the mobility of people and ideas should work at all university levels.

The presented above approach includes only the most general problems arising on the way. Nevertheless, the presented approach is based on the quite real experience of the short-courses training of the students from European universities at IFMO Univertsity. The first university, which started to participate in this international program together with IFMO was Uppsala University, Sweden. Within five years the Swedish students take the two weeks laboratory training in different optical labs at IFMO University. Using the same module-type education scheme we successfully launched at IFMO University the Summer School Program in Laser Physics for Uppsala students. The Summer School Program lasts a one month and consists from a few independent short modules, which can be chosen by foreign teachers and their students in advance. Another way of successful international cooperation on-going at IFMO University is "sandwich" optical programs for PhD students. The regular questioning of foreign students and teachers participating in optical training in St-Petersburg State IFMO University demonstrates their exclusive interest to such international cooperation in the field of optical education. 